\title{
The Bearded Ones: Dwelling in a History of Radicalism, Authenticity, and Neoliberalism
}

Russell Cobb

Journal of French and Francophone Philosophy - Revue de la philosophie française et de langue française, Vol XXV, No 1 (2017) 49-60.

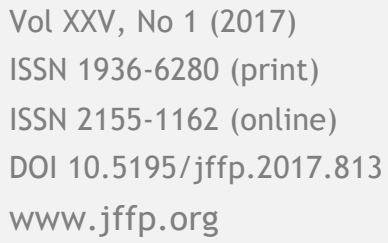

\section{(oc) EY-NO-ND}

This work is licensed under a Creative Commons Attribution-Noncommercial-No Derivative Works 3.0 United States License.

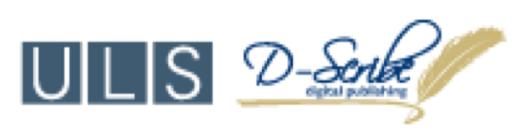

This journal is operated by the University Library System of the University of Pittsburgh as part of its D-Scribe Digital Publishing Program, and is co-sponsored by the University of Pittsburgh Press 


\title{
The Bearded Ones
}

\section{Dwelling in a History of Radicalism, Authenticity, and Neoliberalism}

\author{
Russell Cobb \\ University of Alberta

\section{Dwelling in the Beard}

Beards are a sort of dwelling. Much like Heidegger's linguistic play with related etymologies of building and dwelling, beards are in a constant state of becoming, forever changing length, shape, and color. To the personusually, but not always, a man-who grows a beard, the end product is always projected out into the future, like Heidegger's concept of being. The beard is trimmed and groomed constantly; it is cultivated in a way that feels authentic to its wearer. But the same ontological problems that Heidegger applies to dwelling in a home also apply to beards. Long facial hair symbolizes wisdom in many cultures, but anyone who has grown a beard can attest to the existential dilemma of long facial hair. I didn't recognize you with the beard, someone will say. Beards can serve as symbols of erudition, yes, but they are also masks for our social selves. The beard is, after all, is a curious appendage, as it is an extension of the self, but not the self per se. Herman Melville called beards "suburbs of the chin." If, like Heidegger, we are to see being as not a fixed entity divorced from other beings, but a beingin-the-world, a set of relations among other beings, then beards are not simply static accessories or styles, but an example of the slippery nature of being itself.

Beards in literature have never represented one particular attitude, religion, or ideology. As we see in Ginsberg's vision of Whitman in "Howl," beards "point" in certain directions, symbolizing different--and even contradictory-ideas at different times. They are part of a complicated symbolic order. The beard can symbolize industrious machismo or bohemian sensitivity, depending upon the cultural context. Indeed, throughout history, facial hair has been remarkably adept at accommodating all manner of religious orthodoxies, crank scientific theories, and ideological manifestos. In antiquity, beards could symbolize a man's status as

Journal of French and Francophone Philosophy | Revue de la philosophie française et de langue française Vol XXV, No 1 (2017) | www.jffp.org | DOI 10.5195/jffp.2017.813 
upstanding citizen, while, at other times, the beard symbolized precisely the opposite; it was "a mark of slovenliness and squalor." ${ }_{1}$ In more contemporary times, beards have been synonymous with political radicalism (beards have an illustrious history in communism in particular) but, at other times, have been fashionable among capitalist robber barons, especially in the later 19th century. In our current neoliberal era, in which beards can serve as a "brand" to the freelance writer or independent app designer, beards are the domain both of the urban hipster and the Islamic radical, the professional baseball player and the Orthodox Jew.

Any attempt to perform some sort of exhaustive semiotic analysis of beards, then, will arrive at the same conclusion: the beard is a physiological reality, but its meaning is a cultural construct, often reflecting changing notions of masculinity or "manliness." It is a biosocial phenomenon, what Paul Rabinow terms as the construction of identity based on genetic or biological foundations. As such, it is impossible to truly "dwell" in the beard. The beard is in a constant state of conflict and becoming; it is a building rather than a dwelling. Most importantly, it is a performance. As we will see in reference to a number of fictional and nonfiction texts, beards may purport to connote cultural authenticity in the form of a lumberjack or guajiro (a Cuban peasant), but their very state of becoming, their instability of meaning, often undercuts any claim to authenticity.

Even the very term beard is deceptively unstable. Can one even speak of The Beard? Surely a closely cropped beard signifies something different than a goatee, which in turn is different than muttonchops. Are muttonchops even beards at all? At what point on the face do sideburns become beard? And what of the multiple forms of the moustache? And what about female facial hair? As tempted as I am to sketch some preliminary Universal Theory of the Beard, I shall resist and speak only of one variant of facial hair: that worn by the "bearded radical" or "the bearded rebel" in the context of the past fifty years in the context of the international appeal of the Cuban barbudos (the bearded ones) in literature.

The bearded radical/rebel is a historical figure and stock character dating from the 19th century, but one which has continued to surface in particular moments of political and cultural revolution, from early 19th century Britain to the late 1950s in Cuba. Christopher Oldstone-Moore has pointed to Charles Kingsley's 1847 novel, Yeast: A Problem as a representative novel depicting a bearded radical, one who was outside the bourgeois norms of respectability. One of the novel's main characters, Claude Mellot, holds forth on the manly radicalness of the beard in conversation with the "effeminate" Argemone, an upholder of conservative Anglican values:

Our forefathers were not ashamed of their beards; but now even the soldier is only allowed to keep his moustache, while our quill-driving

Journal of French and Francophone Philosophy | Revue de la philosophie française et de langue française Vol XXV, No 1 (2017) | http://www.jffp.org | DOI 10.5195/jffp.2017.813 
masses shave themselves as close as they can; and in proportion to a man's piety he wears less hair, from the young curate who shaves off his whiskers, to the Popish priest who shaves his crown!

Mellot goes on to defend the beard as the "natural" look of a man, although the prudish norms of the era had made facial hair to signify a wild and "unrefined" look. This was perhaps the first instance of the beard being synonymous with the idea of authenticity, a trope that will return-as we shall see-in our present moment. Oldstone-Moore points out that shortly after the publication of Yeast, beards shed their radical connotations and went mainstream during the Victorian period. As society began to industrialize and gender roles started to shift, beards served a dual function. The conventional wisdom changed, and a new consensus was formed: beards were outward symbols of a man's vitality, demonstrating his superiority to women:

At the core of this consensus was the idea that beards were integral to that elemental masculinity which still pertained in the modern age, first by contributing to men's health and vitality, and second by serving as the outward mark of inward qualities-particularly independence, hardiness, and decisiveness-that were the foundations of masculine authority. As such, they came to symbolize the 'natural' superiority of men over women, and more vigorous men over their effete counterparts.

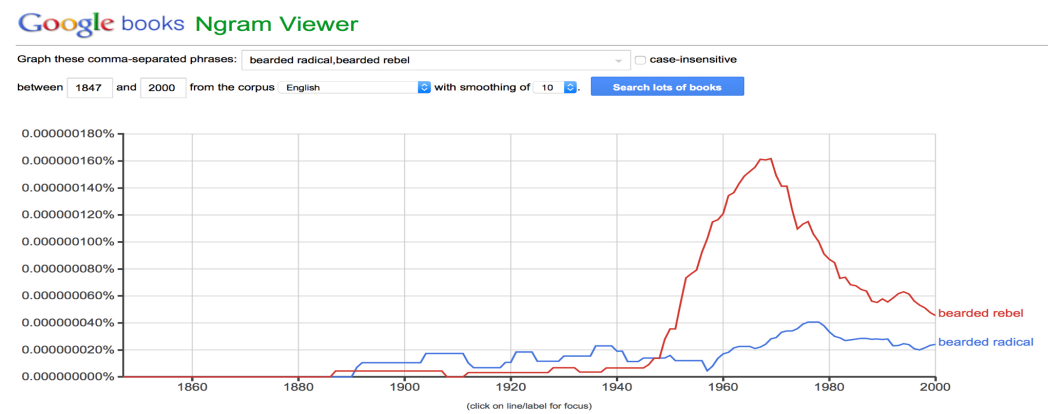

Even though the "bearded radical" dropped from the scene during the Victorian Period as the beard achieved mainstream respectability, it would return with a vengeance during the 20th century. In this Google Ngram, for "bearded radical" and "bearded rebel," we can see that these phrases have had an interesting trajectory over the past 100 years. After various ebbs and flows throughout the 20th century, the phrase starts to explode in the discourse in the late 1950s, before subsiding in the 1980s. There are probably many explanations for this, but I'd like to focus on one that will, I hope, highlight how much the association of beards with authenticity and masculinity has changed in the past few decades.

Journal of French and Francophone Philosophy | Revue de la philosophie française et de langue française Vol XXV, No 1 (2017) | http://www.jffp.org | DOI 10.5195/jffp.2017.813 


\section{The Allure of the Barbudos}

The proliferation of the phrases "bearded rebel" and "bearded radical" in the corpus of English-language texts demonstrated in the nGram corresponds with media attention given to the Cuban Revolution in the late 1950s and throughout the 1960s. The revolutionaries, including Che Guevara, Fidel Castro, and Camilo Cienfuegos, all wore peasant-style beards as they fought and trained in Cuba's Sierra Maestra mountains. Before the leaders had garnered individual attention, they were often referred to simply in the collective as the barbudos, the "bearded ones," who had little in the way of concrete ideology but much in the way of romantic allure in the foreign press. The trend of romanticizing the barbudos began with New York Times reporter Herbert Matthews who followed the revolutionaries as they grew out their beards and finally began to shape their ideology in the Sierra Maestra mountains during the late 1950s. Herbert Matthews, a reporter with a literary bent, described Castro in terms that the Cuban leader's literary hero, Ernest Hemingway, might have seen as fitting:

Taking him, as one would at first, by physique and personality, this was quite a man:

a powerful six-footer, olive-skinned, full-faced, with a straggly beard. He was dressed in an olive gray fatigue uniform and carried a rifle with a telescopic sight, of which he was very proud. It seems his men have something more than fifty of these and he said the soldiers feared them.... The personality of the man is overpowering. It was easy to see that his men adored him and also to see why he has caught the imagination of the youth of Cuba all over the island. Here was an educated, dedicated fanatic, a man of ideals, of courage and of remarkable qualities of leadership. ${ }^{4}$

Although this description of Castro is non-fiction and separated by over a century and a continent from Kingsley's Mellot, they share similar traits: physical prowess, facial hair, and political defiance, thus making them both bearded radicals. A cultural/literary type has been firmly established, but the birth of the countercultural movement in the 1960s complicated the stereotype. A similar trope emerged in C. Wright Mills's Listen Yankee!, in which the American sociologist argued that what was happening with the barbudos would determine the direction of all of Latin America. Fidel Castro and his signature beard went on a post-Revolution publicity tour in the United States in 1960, garnering the adoration of many African-Americans and Latinos when he stormed out the Waldorf-Astoria and relocated to Harlem. Five years later, during the apogee of the "bearded rebel" moniker, another bearded radical, beat poet Allen Ginsberg, traveled to Cuba to judge a literary prize known as Casa de las Américas. After the Cuban Revolution of 1959 reorganized the cultural scene on the island around the project of building socialism, Casa de las Américas established itself as the premier

Journal of French and Francophone Philosophy | Revue de la philosophie française et de langue française Vol XXV, No 1 (2017) | http://www.jffp.org | DOI 10.5195/jffp.2017.813 
cultural clearinghouse of magazine publishing, literary prizes, and cultural events. Havana had become a center of literary publishing in the Spanishspeaking world and the so-called Boom of Latin American literature was just beginning.

Ginsberg wanted to go to Cuba to show solidarity with the nation's ongoing struggle against the United States, especially its embargo on exports (a policy the Cubans refer to, not as an embargo, but as a "bloqueo" [blockade]). He followed in the footsteps of the "Venceremos Brigade," a U.S.-based group consisting primarily of students who volunteered to work in Cuba cutting sugarcane, the most important Cuban export. On the surface, groups such as Fair Play for Cuba and the Venceremos Brigade were political organizations whose aims were decolonization and solidarity with "Third World" movements and opposition to U.S. aggression in places. Despite the noble aims of fostering an international postcolonial movement, however, many of the writers and thinkers in these groups held up the barbudos as a sort of Noble Savage. Writers like C. Wright Mills and Ginsberg romanticized the image of the dark-skinned bearded radical as authentic, an antidote to their own disaffection with bourgeois society. Jean-Paul Sartre's high-profile visit to Cuba to visit with Guevara, in which the French existentialist was photographed with the cigar-smoking, fatigues-wearing, cigar-smoking rebel, cemented the image of the barbudo as someone who had found the solution for the inauthenticity of the modern capitalist condition as described by existentialist philosophers.

In his fictional memoir of Fidel Castro, Norberto Fuentes describes the Cuban leader as purposefully working on his beard over the years, acutely aware of its "everlasting" symbolism. The Autobiography of Fidel Castro imagines the interior life of the Bearded One, the braggadocio and the resentment he feels towards many of his former allies. The beard is but one of Castro's hyper-masculine attributes in the novel, which includes a twopage detailed description of the leader's large genitals narrated by Fuentes's fictional Castro. Although in Fuentes's imagining, Castro initially grows out his beard because the circumstances of mountainous guerrilla warfare demanded it, Castro is also proud of the fact that his formerly smooth face now sports a manly beard. Not only did it give him gravitas, the "newly cultivated beard [was] also indicative of small changes in habits and the acquisition of new gestures." ${ }_{5}$

The growth of the beard is intimately connected to the sexual mythology of the barbudos, a connection that spread far beyond Latin America. The sexual appeal of Che Guevara's beard is a backdrop to Ana Menéndez's 2003 novel, Loving Che, in which the protagonist learns that she may be the love child of the Argentine revolutionary. One of the narrators, the protagonist's mother, evokes Che's beard in a series of sexual encounters: "I breathe the moist soft of his beard and listen to the blood pumping beneath the rise in his neck." ${ }_{6}$ On the following page, the novel

Journal of French and Francophone Philosophy | Revue de la philosophie française et de langue française Vol XXV, No 1 (2017) | http://www.jffp.org | DOI 10.5195/jffp.2017.813 
reproduces a "come hither" photograph of Che sipping mate, propped up on one elbow, shirtless in bed.

The allure of the barbudo was not always sexual, however. In fact, it became connected with vague notions of a countercultural revolution whose ideological underpinnings remained somewhat obscure. Rian Malan narrates his own romanticism with the barbudo Che Guevara in his memoir, My Traitor's Heart, thusly:

In 1967 or thereabouts, Life carried a story about a Frenchman named Regis Debray who went off to Bolivia with one Che Guevara. Their mission was to help oppressed Indians in their fight for freedom. I gathered from the text that Che was a disreputable something called Communist, but he cut a pretty dashing figure in the pictures, with his long black hair, combat boots, beard, and beret. [my emphasis] I thought, whoa, Communism, that's for me. The plight of Bolivia's Indians seemed rather similar to the wretched lot of the blacks in my own backyard, so I put two and two together, and bingo, I was the Just White Man, champion of the downtrodden, sworn foe of racism, and ardent proponent of Communism, whatever that was supposed to be.

The beard, then, is not simply a symbol of authentic masculinity, but a rejection of all that is artificial about modern life. The beard, in this mode, is akin to Heidegger's chalet at Todtnauberg, a place timeless and authentic, an autochthonous place rooted in the Blut und Boden of the masculine subject.

Indeed, the Cuban Revolution itself turned increasingly to the soil after a failed experiment with state-sponsored industrialization in the early 1960s. By the time of Ginsberg's visit, the Revolution was emphasizing development of the countryside and preserving its traditional folkways: the music of the guajiro, the traditions of santeria, etc. During this era, the drive to cut sugarcane became an organizing principle, not only of the Cuban economy (which exported sugar to the Eastern Bloc in exchange for oil and consumer goods), but also of social values. Cutting sugarcane was an essential feature of the "Hombre Nuevo" (New Man) under socialism. Ablebodied men were expected to cut sugarcane for what Che called "the moral incentive" of building socialism, not the inauthentic capitalist incentive of money. Homosexuality at the time was a considered an urban, bourgeois moral condition that could be corrected by re-education. Many-perhaps the majority-of the most prominent Cuban writers of this period were gay (e.g., Virgilio Pinera, Jose Lezama Lima, Reinaldo Arenas), as were many of the writers, such as Ginsberg, who traveled to Cuba with the various solidarity movements of the 1960s. The countercultural beards of the new gay pride movement often created friction with the barbudos as the 1960s progressed. The tension has been described by Ian Lekus as a conflict that was as much about sexuality as it was about politics:

Journal of French and Francophone Philosophy | Revue de la philosophie française et de langue française Vol XXV, No 1 (2017) | http://www.jffp.org | DOI 10.5195/jffp.2017.813 
Moreover, young white men alienated from the clean-cut middle-class Cold War culture of consensus found in the "bearded rebel" a role model who fused revolutionary protest and virility. The Fair Play for Cuba Committee mobilized many students later active in the New Left in support of better U.S.-Cuban relations after the chill had set in. While Castro embodied the various hopes of his American supporters, some of these fidelistas denounced the Cuban elites who fled to Florida after 1959 as los maricones (faggots). Slurring anticommunist Cubans as homosexuals not only represented the counterpoint to Castro's reputed virility but also evoked the sexual economy that had thrived in Havana under Batista.'

This conflict gave rise to a battle of the beards, one that the Cuban revolutionaries tried to control through literary culture. Beards were an important symbol of the ongoing Revolution. Indeed, the newspaper for young radicals was Juventud Rebelde and its cultural supplement, founded in 1966, was titled "El Caiman Barbudo." The Caiman is a Cuban crocodile, a highly aggressive crocodile found only in Cuba. Why is it bearded? It was a bit of absurd humor mixed with a tribute to the Revolution. The editors explained in the first edition that the "bearded" aspect of the title was an homage to the barbudos, the revolutionaries.

Little did Ginsberg know that he was stepping into a culture war to determine the direction of the Cuban Revolution of 1959. Castro was the "bearded rebel scholar," ${ }_{10}$ but Ginsberg's Whitmanesque beard was also part of a rebellion, one that paid homage to both Whitman and Federico Garcia Lorca, another queer icon. Ginsberg's beard was a symbol as well, not of virile machismo, but of his Whitmanesque voracious sexual appetite, well documented in his letters from Cuba. Ginsberg had his own bearded lineage to represent in 1965, that of the "queer beard," which dates back to at least Walt Whitman, whose "queer beard" was eulogized by the Spanish poet Federico Garcia Lorca: "Ni un solo momento, viejo hermoso Walt Whitman / he dejado de ver tu barba llena de mariposas." "

In Garcia Lorca's vision of Whitman's beard, it is "full of butterflies" [mariposas], a word that has spawned a panoply of slang words for "gay" in Spanish. Whitman's beard is "full of gays," in a more subversive reading. Ginsberg's beard was a beard, then, not only of the militant New Left, but also of an alternative gay history. So while Castro's beard was undeniably part of the sex appeal of the young revolutionaries, it also symbolized the cult of masculinity within the Revolution. Che Guevara's beard was a symbol of the socialist New Man who dedicated himself-at least partly-to the national project of a record sugarcane harvest. While the Revolution did challenge some notions of gender roles in Cuba, it still upheld an ideology that the Nation's honor code must be upheld by a patriarchy. The paradox of a communist patriarchy is that while workers are supposedly seen as equals in the struggle to build a new Nation, that Nation is embodied in the heteronormative Man. This discourse plays itself out in the emphasis on

Journal of French and Francophone Philosophy | Revue de la philosophie française et de langue française Vol XXV, No 1 (2017) | http://www.jffp.org | DOI 10.5195/jffp.2017.813 
"virility" in Guevara's writings, especially those regarding socialism and the construction of the New Man. It bears keeping in mind that the New Man, beard and all, was not merely discursive but was also instrumentalized in the UMAPs (Unidad Militar de Ayuda de Producción), essentially concentration camps for the 1960s in which gay men were sent to do forced labor and become "real men." As Rafael Ocasio notes, male homosexuality was a threat, in part, because it did not "produce" new workers and was seen as similar to capitalism: It preyed upon the virile force of labor without producing anything new. The beard was then a throwback to the guajiro, a Cuban peasant whose emblematic image usually included a straw hat, long black beard, and cigar. As the New Man struggled to meet the high expectations of a ten million ton sugar harvest in 1971 (the goal was never met), cultural production once again centered on folklore.

Urbane and existentialist films and novels such as Memories of Underdevelopment were shunned as the first testimonios were published. These testimonios, such as Miguel Barnet's Biography of a Runaway Slave, took place in the countryside, with rural, Cuban themes. After Ginsberg's expulsion for sexual deviance in 1965, the Revolution turned away from some of the more playful types of cultural production that came out of early post-revolutionary magazines such as Lunes de Revolución. Meanwhile Che Guevara's iconic image, as captured by Alberto Korda and reprinted worldwide, started to capture the imagination of a new generation of rebels who knew little of the Revolution's sordid history of homosexual persecution. Che's straggly beard and hair, his eyes gazing in the distance came to symbolize a vague sort of rebellion that could easily be co-opted as an intellectual shortcut. It could also be a way to "brand" a product as rebellious, that ultimate irony of the barbudos' afterlife during the age of neoliberalism.

\section{Some Remarks about the Beard under Neoliberalism}

As mentioned at the beginning of this article, beard symbolism was highly contested throughout the 19th century, when the phrase "bearded radical" first came into vogue. Until recently, beards signified specific things, usually religious or political movements. Oldstone-Moore writes that in "the early nineteenth century beards indicated particular radical political affiliations, including socialism or Chartism, and were generally unfashionable." Stephen Mihm recently wrote in the New York Times that while Karl Marx grew his beard to defy the bourgeoisie, CEOs of powerful companies are now growing beards. ${ }^{13}$ Beards have risen and fallen in popularity among elites as notions of masculinity and the nature of work have evolved. As seen from the nGram referenced earlier, the ideas of radicalism and rebellion associated with beards have experienced a slow and steady decrease from the early 1970s onward. While the afterlife of Che Guevara's visage from

Journal of French and Francophone Philosophy | Revue de la philosophie française et de langue française Vol XXV, No 1 (2017) | http://www.jffp.org | DOI 10.5195/jffp.2017.813 
Korda's famous photograph still seems to evoke a vague notion of rebellion, the specificity of beard symbolism has been lost. This makes the current revival of the beard, as seen on baseball players, reality television celebrities, rock musicians, and ex-politicians ( $\mathrm{Al}$ Gore), difficult to parse. On the one hand, we still have the rebellious, dissident, radical beard. This is the hipster or lumbersexual beard, which seems vaguely countercultural, but, like the ubiquitous image of the Che Guevara t-shirt, lacks any coherent set of beliefs. On the other hand, there is a certain strain of atavism in many contemporary beards, ranging from Osama Bin Laden to Phil Robertson, whose beards attempt to evoke a moral purity and religious devotion, even if it is in the context of a media spectacle. The beard can no longer have a manifesto, but it can help solidify an image. It can create a brand.

A caller to the Nation Public Radio program On Point in January, 2015 described his own beard as an effort to stand out, to be distinct. The caller said he was in his mid-20s, trying to establish a professional career, and having a hard time standing out from a crowd of other recent college graduates. Then he said something that really caught my attention: Growing a beard, he claimed, helped him with his "branding." "s People had remembered him because of his unique facial hair. There is perhaps no term that underscores our contemporary economy more than branding. The rise of the beard thus connects two seemingly unrelated phenomena: the decline of the male worker and the rise of the freelance economy. Women are fast closing all kinds of gender gaps with men, as Hannah Rosin documents in the End of Men and the Rise of Women. Men are no longer essential as the paradigm of patriarchy is broken. Beards are either worn ironically by urban-dwelling "lumbersexual" hipsters or by celebrity and media figures looking to further cement their brand, their recognition in the celebritydriven economy of what remains of the traditional media industry. What do the beards of Houston Rockets player James Harden, the Duck Dynasty brothers, and Ben Affleck have in common? Nothing. They are simple fashion accessories. In antiquity, beards connoted widely different ideas, but there were a range of ideas that could apply in any given situation. With the advent of modernity, beards could be indicative of radicalism in 19th century literature or the iconic rugged individual. Under neoliberalism, though, the beard has no underlying meaning; it is all signifier and no signified.

Perhaps nothing underscores this point more than an Etrade commercial entitled "Opportunity is Everywhere." In the commercial, a character that appears to be based on the fictional character Frank Underwood in House of Cards is scanning a street scene in a densely populated American city. All around him, hipsters of various races and ethnicities are skateboarding, biking, and walking by, all of them sporting ostentatious facial hair. The character (Kevin Spacey) directly addresses the viewer as "you." As the Spacey-Underwood character sips a coffee, he looks 
into the camera and says: "You my friend, can recognize when a trend has reached critical mass." ${ }_{15}$

In the world of Etrade, a financial trading platform that purports to give its clients access to a broad range of tools to trade equities and commodities, beards are simply another element in a neoliberal economy. The Kevin Spacey narrator-character senses an opportunity. "When others focus on one thing, you see what's coming next. That's what a type-E does." ${ }_{16}$ Towards the end of the commercial, we see another hipster emerging cleanly shaven from a barbershop, contentedly stroking his smooth chin. The Underwood character's sidekick, an entrepreneurial-looking young woman, takes notes. No longer is the woman an inferior, as she was during the Beard Movement of Victorian times. She walks beside Spacey during the commercial, a stand-in for the savvy eTrade investor, ready to invest her money in the next start-up or IPO. She is ready to lean in on the bearded ones. In this last scene, the woman accompanying Spacey smiles with a look of insight. She has realized that the trendiness of the beard may be coming to an end. The revival of smooth men's faces may be, in the words of the commercial, "what's coming next." In a neoliberal world, facial hair is more than fashion, sexuality, or ideology. It is business. Now is the time to invest in clean faces, the woman seems to be thinking. Perhaps by buying shares of Gillette, or opening a barbershop catering to hipsters, or something else. The beards of lumbersexuals, hipsters, revolutionaries, and bearded radicals all fall back to the soil, swept away by capitalism's need for creative destruction.

Confronted with the inauthenticity of modern life, the beard would seem to serve as a reaffirmation of authenticity. If a shaved face, a moustache, or a goatee is cultivated, the full beard is wild. It might seem to provide a path to a Heideggerian dwelling. Not shaving, after all, means "sparing" facial hair, the essence of dwelling: "The basic character of dwelling is to spare, to preserve.... Dwelling itself is always a staying with things. Dwelling, as preserving, keeps the fourfold in that with which mortals stay: in things." ${ }_{17}$ Revolutionary beards such as Ginsberg or Guevara's, anti-secular and anti-modern beards such as those worn by the Robertson family on Duck Dynasty, for all their different ideological manifestations, share with Heidegger a disdain for the artifices of modernity, marketplace, and utilitarianism.

Despite my own facial growth, I believe that the beard is a symbolic gesture toward an ahistorical authenticity, a symptom of our homelessness, of the lack of dwelling in a globalized age. Peter Berger might as well have been writing about modern male facial hair when he writes that in "in a world of dignity (the modern age of individuality that he contrasts with the pre-modern world of honor) ...the individual can only discover his true identity by emancipating himself from his socially imposed roles." Whether we construe those imposed roles as capitalistic "false consciousness," the

Journal of French and Francophone Philosophy | Revue de la philosophie française et de langue française

Vol XXV, No 1 (2017) | http://www.jffp.org | DOI 10.5195/jffp.2017.813 
Cartesian subject, or the secular marketplace, the bearded man seeks to liberate himself: "In a world of dignity, history is the succession of mystifications from which the individual must free himself to attain 'authenticity'." ${ }^{18}$

In our neoliberal age, though, can authenticity be anything more than a brand whose use of history consists of fragmented and carefully curated samplings? Is not authenticity a series of mystifications involving multiple gazes among multiple Others? Take a Che Guevara t-shirt for sale in the staged authentic section of Old Havana made safe for tourists. It is made in China and marketed to a new influx of Americans who want to see the socialist island before it is "ruined" by corporations-the very corporations that shape their social and cultural lives in the United States. The Che t-shirt, in turn, features a pop-art take on a photograph in the aftermath of an actual Cold War battle when Che Guevara was in the throes of defining the socialist "New Man." This New Man would not work not for capital or the accumulation of wealth, but to advance the cause of human solidarity, a cause directly undermined by the reality of the t-shirt for sale. No matter, though: in the manufacturing of authenticity, history is remolded through mystification. Unpacking the layers of mystification, we are left with a beard full of symbolic fury and signifying very little.

Even if we accept that "sparing and preserving" are the keys to the ontology of the beard, we are faced with the fact that beards are incapable of truly existing outside a symbolic order. That order belongs to a staging of authenticity that would seem, at first glance, to pose as an antidote to our modern globalized world. The beard always harkens back to a more authentic age. When, exactly, that authentic age existed can never be pinpointed with any certainty. We are, as Berger says, "curiously ahistorical," relying on pastiche, sampling, and shout-outs to other ages, rather than seriously attempting to reconstruct them. Beards, therefore, suggest a mode of authenticity foreclosed by the performative nature of our social lives. What, exactly they symbolize, though, is entirely driven by context. A beard can connote baseball playoffs, religious zealotry, queer solidarity, or anti-capitalist revolution. Beards are green-screens upon which we project our various obsessions with authenticity.

\footnotetext{
${ }^{1}$ Smith, William, William Wayte, and G. E. Marindin, A Dictionary of Greek and Roman Antiquities (London: J. Murray, 1890) 127.

${ }^{2}$ Charles Kingsley, Yeast: a Problem/by Charles Kingsley, Jr. - 3rd Edition (London: J. W. Parker and Son, 1853), 56.
}

Journal of French and Francophone Philosophy | Revue de la philosophie française et de langue française Vol XXV, No 1 (2017) | http://www.jffp.org | DOI 10.5195/jffp.2017.813 
${ }^{3}$ Christopher Oldstone-Moore, “The Beard Movement In Victorian Britain," Victorian Studies 48, no. 1 (2005), 8.

${ }^{4}$ Herbert Matthews, “Cuban Rebel Is Visited in Hideout,” New York Times (February 24, 1957): 1.

${ }^{5}$ Norberto Fuentes, The Autobiography of Fidel Castro (New York: W.W. Norton \& Co., 2010), 234.

${ }^{6}$ Ana Menéndez, Loving Che (New York: Atlantic Monthly Press, 2003), 99.

${ }^{7}$ Ibid., 100.

${ }^{8}$ Rian Malan, My Traitor's Heart: A South African Exile Returns to Face His Country, His Tribe, and His Conscience (New York: Grove Press, 1990), 42.

${ }^{9}$ Ian Lekus, “Queer Harvests: Homosexuality, The U.S. New Left, and the Venceremos Brigades to Cuba," Radical History Review 89 (2004): 62.

${ }^{10}$ Van Gosse, Where The Boys Are: Cuba, Cold War America and the Making of a New Left (London: Verso, 1993), 110.

11 "Not for a moment, beautiful old Walt Whitman/ Have I stopped imagining your beard full of butterflies." See Federico García Lorca, “Ode to Walt Whitman,” trans. W.S. Merwin, in The Selected Poems of Federico Garcia Lorca, eds. Federico García Lorca and Donald M. Allen (New York: New Directions, 1955), 126. For the full text of the poem, see 125-134.

12 Oldstone-Moore, “The Beard Movement In Victorian Britain," 7.

${ }^{13}$ Stephen Mihm, “Why C.E.O.s Are Growing Beards," New York Times, Sunday Review (November 28, 2014): 1 .

14 “Beards Are Back.” On Point with Tom Ashbrook RSS. January 5, 2015.

15 “E*TRADE Commercial: ‘Opportunity Is Everywhere’.” YouTube. July 16, 2015.

${ }^{16}$ Ibid.

${ }^{17}$ Heidegger, “Building Dwelling Thinking,” 148-149.

${ }^{18}$ Peter Berger, “On the Obsolescence Of The Concept Of Honor” European Journal of Sociology / Archives Européennes De Sociologie / Europäisches Archiv Für Soziologie 11, no.2 (1970): 341 342.

Journal of French and Francophone Philosophy | Revue de la philosophie française et de langue française Vol XXV, No 1 (2017) | http://www.jffp.org | DOI 10.5195/jffp.2017.813 